Témoigner Témoigner. Entre histoire et mémoire

Getuigen Revue pluridisciplinaire de la Fondation Auschwitz

$124 \mid 2017$

La musique dans les camps

\title{
Orkesten in de naziconcentratiekampen: functie en receptie
}

Les orchestres dans le système concentrationnaire nazi : fonctions et réception

\section{Amaury du Closel}

Traducteur : Gorik de Henau

\section{(2) OpenEdition \\ Journals}

\section{Édition électronique}

URL : https://journals.openedition.org/temoigner/5764

DOI : $10.4000 /$ temoigner.5764

ISSN : 2506-6390

Éditeur :

Éditions du Centre d'études et de documentation Mémoire d'Auschwitz, Éditions Kimé

Édition imprimée

Date de publication : 2 avril 2017

Pagination : 88-101

ISBN : 978-2-930953-00-7

ISSN : 2031-4183

\section{Référence électronique}

Amaury du Closel, «Orkesten in de naziconcentratiekampen: functie en receptie», Témoigner. Entre histoire et mémoire [Online], 124 | 2017, Online op 30 novembre 2021, geraadpleegd op 01 décembre 2021. URL: http://journals.openedition.org/temoigner/5764 ; DOI: https://doi.org/10.4000/temoigner 5764

Tous droits réservés 


\section{Orkesten in de naziconcentratiekampen: functie en receptie}

Amaury du Closel is componist en dirigent. Hij is oprichter van het Forum Voix Etouffées, dat van componisten die lachtoffer werden van nazisme en pedagogische workshops organiseert Amaury du Closel is uteur van Entartete Musik: Musiques interdites sous le llle Reich (2015).

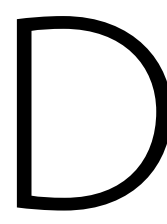

at muziek en dus ook orkesten een rol speelden in de nazikampen i en fenomeen dat nu algemeen bekend is. Toch werd er maar vanaf de de bijzondere omstandigheden waarin ze werd gebruikt de grenzen van het verstand te boven te gaan. Maar de bevestiging kwam er toen een reeks getuigen naar voren traden, een aantal zelfs al in 1946, meer bepaald musici die an Als nazcostu(concentratiekampen, getto's, gevangenissen) waarin het Derde Rijk van 1933 to het einde van de Tweede Wereldoorlog politieke tegenstanders opsloot en deed verdwijnen, waarmee het de arbeidskracht uitbuitte van de inwoners van veroverde landen en van bepaalde krijgsgevangenen die niet door het Verdrag van Genève werden beschermd, en waarmee het vanaf 1941 specifieke etnische en religieuze

Ze verschillen van de gevangenkampen die eigen zijn aan de oorlogstoestand. Dergelijke kampen vielen toen onder het Verdrag van Genève uit 1929, waarin hun werking werd gereglementeerd en waarborgen voor gevangenen werden vastgelegd. Je zult hier dus niets vinden over bijvoorbeed Olvier Messien en anderen die Je zult hier dus niets vinden over bijvoorbeeld Olivier Messiaen en anderen die mponeerden of muziek beoefenden in de Stalags en Oflags. lijks van elke denkbare context van vrijheidsberoving, van de goelags tot de Chileense gevangenissen. Al in de Bijbel is er sprake van muziek, namelijk in psalm 137 over de deportatie van de Hebreeërs naar Babylon, na de overwinning van Nebukadnezar II in de zesde eeuw voor onze jaartelling:

Aan Babels stromen, daar zaten wij, ook weenden wij, als wij Sion gedachten. Aan de wilgen aldaar hingen wij onze citers:

want daar begeerden zij die ons gevangen hielden, van ons een lied,

en zij die ons mishandelden, vreugdebetoon:

Zingt ons een der liederen van Sion. aren tachtig geloof aan gehecht, zozeer leek de relatie tussen kunst en die deel hadden uitgemaakt van het vrouwenorkest in Auschwitz onder leiding van de violiste Alma Rosé (1906-1944). We geven meteen de context van deze kortestudie aan. Als naziconcentratiekamp definiëren we de verschillende detentiecentra groepen uitroeide.

Defunctie van muziek binnen de concentratiekampen verschilt dan weer nauwe-
Het fenomeen kreeg een nieuwe dimensie door de rol die muziek speelde in de Holocaust en de Porajmos van Roma en Sinti. Omdat ze de geprogrammeerde dood van hele volkeren begeleidde, nam muziek in die context een symbolische plaats in, nog versterkt door haar bijzondere belang in de nazipropaganda rond Theresienstadt. De uitzonderlijke ontwikkeling van dat kamp/getto en de persoonlijke rol die beulen - als individuen, dus niet als vertegenwoordigers van de macht - er speelden, zijn symptomatisch voor de centrale plaats die muziek inneemt in de Duitse cultuur. Vanf het prille begin trachtte het naziregime muziek te controleren en in te zetten voor haar eigen programma.

\section{SOORTEN ORKESTEN}

\section{Oprichting en evolutie}

In alle kampen kenden orkesten een vrij gelijksoortige ontstaansgeschiedenis. Vaak nam een groepje musici het initiatief, eerst in het geheim, daarna steeds vaker met goedkeuring van de SS.

Kort na de oprichting van het kamp Buchenwald in 1937 vormde de SS een orkestje met zigeun orkeste met zige geen van de len vormdenopnieuw zigeunerseenensenble onder leiding van de homoseksuele accordeonistWheln Heckmann. Hetspeeldep feesjesvan Prominenten (bevoorrechte gevangenen) en de SS in het kampbordeel. In Dachau, dat in 1933 openging, werd het eerste muziekensemble in 1938 gecreëerd door de componist Herbert Zipper (1904-1997). Het functioneerde eerst stiekem en werd daarna geduld door de kampoverheid. In 1940 verkreeg een groep Tsjechische gevangenen de toestemming om een salonorkest op te richten. Het bracht lichte muziek tot vermaak van kapo's en SS'ers.

De kampen werden uitgebreid en uit de veroverde gebieden stroomden almaar meer gevangen toe. Daarom besloot de SS de orkesten uit te breiden en ze een grotere rol toe te kennen, om zo het morel van de gevangenen hoog te houden. Begin 1942 vorin 1942 al nieuwe insturs gearresteerde Tsjech Vlastimil Louda in het kamp aangekomen en de formatie gaan leiden. De 32 leden droegen een speciaal uniform. In 1945 telde het orkest ongeveer 120 musici (inclusief 32 blazers en 84 strijkers), onderverdeeld in diverse subgroepen, onder meer een koperensemble.

Begin 1941 besloot de kampcommandant van Dachau een echt orkest in het even te roepen. Op het programma stonden al snel geliefde klassieke werken als de Hongaarse rapsodie nr. 2 van Liszt en de ouvertures tot Orphée aux enfers van Offenbach, La gazza ladra (De stelende ekster) van Rossini en Dichter und Bauervan Suppé. De klarinettist Josef Ulc schreef de arrangementen. In het najaar van 1941 ming van de kampcommandant stonden, was er ook een strijkorkest onder leiding 
van Piet van den Hurk (de dirigent van de NCRV/Nederlandse Christelijke Radio Vereniging). Op hun repertoire stonden werken van Giordani, Händel, Mozart, Beethoven en Grieg; om de censuur van de kampautoriteiten te ontlopen brachten ze het Vioolconcerto van Mendelssohn onder een valse componistennaam. Het orkest in Mauthausen ontplooide zich vanaf augustus 1942 en in de eerstvolgende weken werden heel wat instrumenten geleverd. In 1943 telde het een dertigtal musici en een jaar later ongeveer het dubbele, dankzij twintig nieuw aangekomen leden van het Filharmonisch Orkest van Warschau.

Hetzelfde gebeurde in de kampen in Flossenbürg en Neuengamme. In het eerste telde de Lagerkapelle in 1944 tussen de veertig en de vijftig musici, in het eerste telde de Lagerhapelle in 1944 tussen de veertig en de vijftig musici, in het tweede omvatte het orkest ongeveer vijfentwintig musici, afkomstig uit Frankrijk Italië, Denemarken, Polen, België, Tsjechoslowakije en Duitsland. In Neuengamme bestond van 1942 tot 1944 een tweede orkest. Met zestig tot tachtig musici was he groter dan het vorige en het had verschillende dirigenten, onder anderen de Tsjechische componist en theaterman Emil Burian (1904-1959). Die laatste organiseerde trouwens ook verboden cabaretopvoeringen in het barakkenkamp.

In die periode speelden de kampcommandanten een niet te onderschatten rol bij de ontwikkeling van 'hun' orkest. Het orkest in Neuengamme was opgericht op bevel van kampcommandant Martin Weiss, die bij een bezoek an Auschwitz on bevelvan kan de indruk was gekomen van het eerste orkest dat de SS daar net in het leven had geroepen. Ook het muziekcommando in Natzweiler-Struthof werd in 1942 opgerich door de kampcommandant, Josef Kramer had waarschjhljk het orkest in Auschwitz voor ogen, waar hij in 1941 had gediend en in 1944 bevelhebber zou worden. Hij liet zich van nabij in met de werking van het orkest, zo bestelde hij een trombone en sordino's voor zijn trompettisten

De Nederlandse overheid had het kamp Westerbork in 1939 oorspronkelijk opgericht voor Joden die op de vlucht waren voor het naziregime. In 1942, tijdens de nazibezetting, werd het een doorgangskamp voor zij die er al waren en voor de poor zij die er al waren en voor de Nederlandse Joden. Het stond onder leiding van een Joode reve leven dat bleef doorgaan toen de SS in 1942 de controle over het kamp kreeg. De Joodse raad richtte een strijkorkest op met een dertigtal hoogstaande musici. Maar onder het bewind van de SS'er Alfred Konrad Gemmeker, van 1942 tot 1945 bevelhebber van Westerbork en een ware melomaan, kwam het muziekleven in het kamp pas echt tot een hoogtepunt, vooral op het vlak van cabaret. Grote figuren van de Berlijnse bühne als Max Ehrlich, Kurt Gerron, Willy Rosen, Camill Spira en Erich Ziegler kregentolatingomeabaSpira en Erich Ziegler kregen toelating om cabavoeren.

\section{Uitroeiingscentra}

Er was ook muziek in de uitroeiingscentra, want Auschwitz en Treblinka hadden hun eigen orkesten en ensembles. Auschwitz telde twee mannelijke orkesten; het eerste werd in 1942 opgericht in Auschwitz I, het tweede op het einde van datzelfde jaar in Auschwitz-Birkenau. Het vrouwenkamp in Auschwitz beschikte eveneens over een eigen orkest, onder leiding van violiste Alma Rosé. Zij was de dochter van Arnold Rosé (1860-1941), eerste viool van de Wiener Philharmoniker, oprichter (c) van hetstrjker (1860-194), en bovendien schoonboer van Gustav Mahler. Er waren ook ensenbles in het zigeunerkamp, in de kampen voor gezinnen in Theresienstadt en Birkenau, en in het subkamp Buna-Monowitz (Auschwitz III).

Toen het kamp Treblinka in juli 1942 openging, had de SS een trio gevormd dat moest spelen tijdens hun maaltijden en feestjes. Een echt orkest ontstond pas met de komst van violist Artur Gold, de leider van een bekend jazzorkest uit het getto van Warschau. Hij werd opgemerkt door kampcommandant Kurt Franz, die hem dwong een ensemble van een tiental musici op te richten. Dat speelde eerst in de buurt van de gaskamers om het geschreeuw van de slachtoffers te overstemmen, en vervolgens op de appelplats; op hun repertoire stonden marsen en Poolse en Jiddis Jiddische volksliedjes. Later speelde het orkest ook bij bokswedstrijden en toneelsketches, enter verstrooilngvandeSS. Goldenzijnnnusciwwing toen een deel van de gevangenen in opstand kwam en het kamp met de grond werd gelijkgemaakt.

\section{Getto's}

Orkesten waren heel belangrijk in de getto's, waar de Joodse administratie meer armslag had om een actief cultureel leven te organiseren. Dat was bijvoorbeeld het geval in het getto van Amsterdam, waar geleidelijk alle 140000 Nederlandse Joden werdenond in september concerteerde in de Joodsche Schouwburg (de voormalige Hollandsche Schouwburg) en onder leiding stond van Albert van Raalte.

Het 'modelgetto' Theresienstadt neemt een bijzondere plaats in binnen de Holocaust en de muziekgeschiedenis, maar het getto van Warschau kende het actiefste culturele en muzikale leven. Met zijn 400000 inwoners, die in steeds hachelijker omstandigheden leefden, was het het grootste van bezet Europa. Het telde vijf Jiddische en Poolse theaters, een reeks clubs en cabarets, koren, kamermuziekensembles en een symfonisch orkest.

Het Joodse symfonisch orkest telde tachtig leden afkomstig uit het Filharmonisch Orkest van Warschau, het Poolse Radio-Symfonieorkest en het orkest van het Teatr Wielki (groot theater), aangevuld met gedeporteerde musici uit Berlijn, Wenen en Praag. Het werd opgericht in november 1940 en kende tot 1942 vier orkestleiders: 


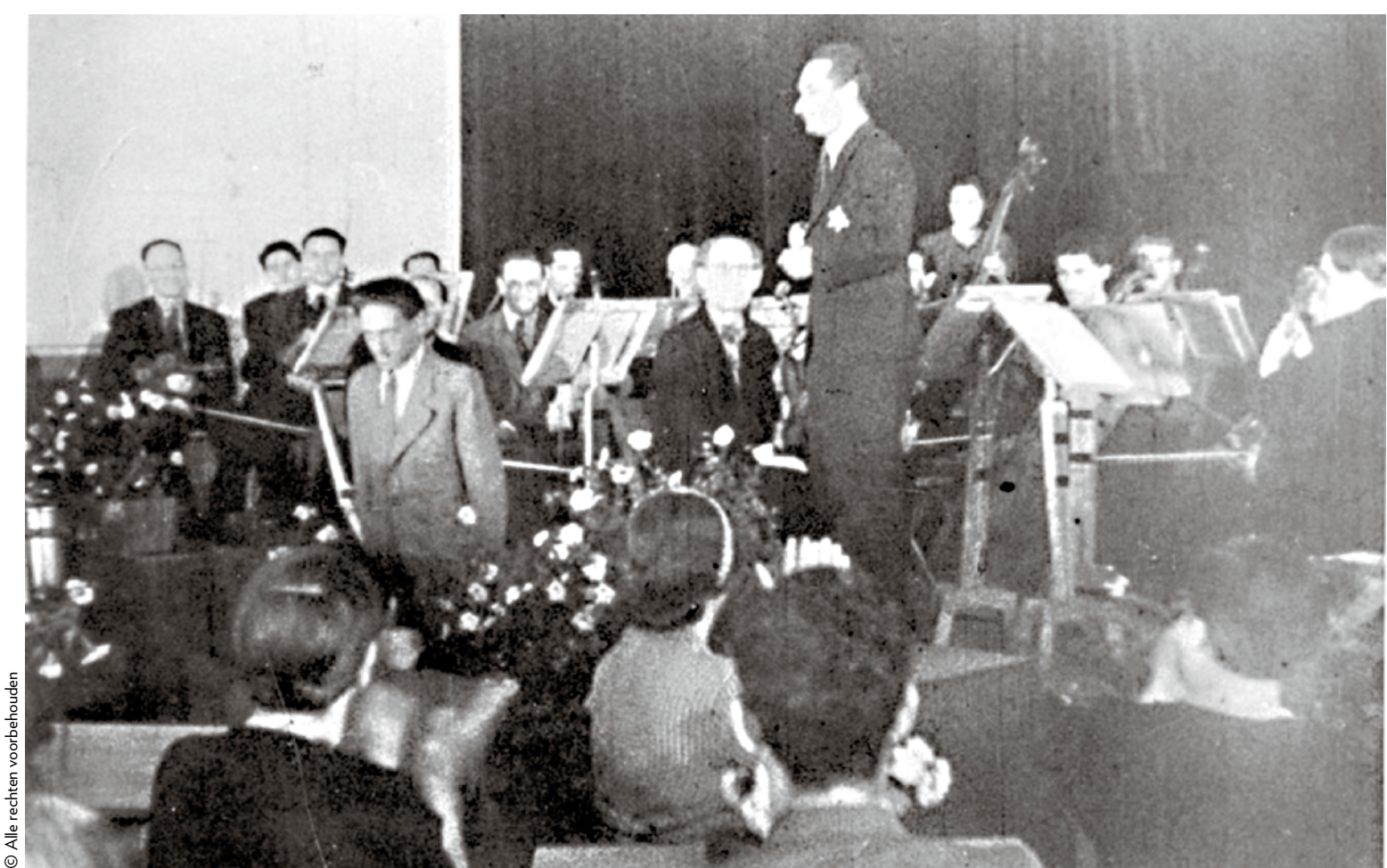

dat was opgericht door cellist Luzian Horwitz en dat, met uitzondering van de eerste violist Karel Fröhlich, exclusief uit Duitse musici bestond. Fröhlich had trouwens zo'n goede reputatie dat hij eerste violist was van de meeste ensembles in het getto. Ook in veel andere getto's was het muziekleven sterk ontwikkeld. Het getto van Łódz, dat naast 250000 Joden ook 5000 Roma telde, beschikte over een symfonisch orkest onder leiding van Teodor Ryder (geboren 1881 - gestorven in Auschwitz in 1944). Voor hij naar het getto werd gedeporteerd maakte hij internationaal carrière bij onder meer de Opéra de Lyon en in 1919 werd hij dirigent van de Filharme bij onder Łódzka. Met een reeks koren (onder andere de Hazamir-zangvereniging), kinderkoren en een revuetheater was Łódz in muzikaal opzicht een bijzonder actief getto. Het Cultuurhuis, waar al die formaties optraden, organiseerde tussen 1940 en 194 meer dan tachtig concerten met over de 70000 toehoorders.

In de zomer van 1941 viel het Duitse leger Litouwen binnen. Het creëerde getto's in Vilnius (Vilno) en Kaunas (Kovno). In Vilnius ontstond een culturele activiteit die sterk werd beïnvloed door de zionistische ideologie van de Bund (de eerste Joodse socialistische beweging, opgericht in 1897) en door de ondergrondse verzetsbeweging die binnen het getto actief was. In december 1941 had de uit Warschau afkomstige dirigent Wolf Durmashkin een orkestje opgericht. Hetgaf in total 35 concerten, met een repertoire dat ook werk van 'Arische' componisten inhield Onder leiding van een rep Yaakov Gershteyn vond op 18 januari het eerste concert plaats, ter nagedachtenis van de vermoorde Joden. Gershteyn had trouwens ook zijn studentenkoor opnieuw samengesteld. Er werd een Hebreeuws koor opgericht en ook een kleiner koor voor liturgische muziek, naast een Jiddisch koor dat samen met een orkest hoofdzakelijk volksmuziek en chassidische liederen bracht.

In bepaalde kampen en getto's werden de beproevingen van de gevangenen uitgekristalliseerd door tangomuziek. Tango's vond je in de getto's van Vilnius, Kovno, Łódz en Białystok, en ook in Auschwitz en Dachau; vaak werden ze geschreven in het Jiddisch, maar ook in het Hebreeuws, Roemeens, Russisch, Pools, Frans en zelfs het Duits. Shmerke Kaczerginsky, die uit het getto van Vilnius was ontsnapt en lid was geworden van het verzet, verzamelde na de oorlog een reeks manuscripten die hij in 1948 in New York uitgaf met de titel Lider fun getos und lagern [Liederen uit de getto's en de kampen].

\section{UNCTIE VAN DE ORKESTEN}

De kamporkesten vervulden volgende functie

1. Het ritme van de werkdag aangeven

2. Spelen tijdens bestraffingen en terechtstellingen

3. Concerteren voor SS'ers en gevangenen

4. Spelen voor de private ontspanning van SS'ers

5. Spelen tijdens officiële plechtigheden

6. De realiteit van het kampleven verdoezelen

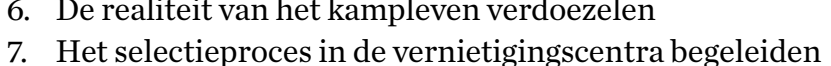


Hun eerste opdracht bestond erin de arbeidsploegen die's ochtends vertrokken te begeleiden met marsmuziek, en 's avonds idem bij hun terugkeer. Daardoor kon het aantal gevangenen (in rijen van vijf) sneller worden geteld, en in voorkomend geval ook het aantal doden dat's avonds door hun kameraden werd gerapporteerd. Dat was een dagelijks weerkerende taak, waarop slechts bij bar slecht weer een uitzondering werd gemalt. Het was trouwens belangrijker de instrumenten voor de zonder voor de kou en de regen te beschernen dan de musicizelf, aldus Szymon Laks, componist en in 1944 dirigent van het Auschwitz-mannenorkest. In de meeste kampen speelden

Spelen tijdens bestraffingen en terechtstellingen

Uit talrijke getuigenissen, soms gedocumenteerd met foto's, blijkt dat de kamporkesten moesten meewerken aan bestraffingen. Op 1 januari 1939 bijvoorbeeld gaf Arthur Rödl, de adjunct-bevelhebber van Buchenwald, tegen het einde van de dag de opdracht om de gevangenen in het gelid te plaatsen. Hij koos er vijf uit, die hij een nacht lang liet geselen terwijl het kamporkest speelde. Op 30 juli 1942 in Mauthausen werd Hans Bonewitz gegrepen afoegaan door het kamporkest werd hij wergeleid om te worden terechtgesteld.

\section{Concerten voor SS'ers en gevangene}

De concerten werden vaak op zondag gehouden, want dat was voor gedetineerden en bewakers de enige rustdag van de week. Ze vonden in de openlucht plaats, op de Appellplatz of in de barakken, voor een publiek van SS'ers en gevangenen, of ze nu Prominenten waren of niet. Van die taak was al sprake in de eerste kampen. Herbert Zipper de componist van het Dachaulied en van augustus 1938 tot 1939 een gedetineerde in Dachau, beschrijft de zondagse concerten in het kamp als volgt:

Je kon het nauwelijks een 'concert' noemen. We hadden geen echte instrumenten, alleen gitaren en strijkinstrumenten die de gevangenen zelf hadden gemaakt. Elke zondag speelden we voor een paar honderd gevangenen een programma van tien of vijftien minuten met allerlei melodieën die ik tijdens de week had gecomponeerd. [...] Maar het ging niet altijd om muziek die ik zelf had geschreven. Veel gevangenen wilden ook composities horen in de trant van de Habanera uit Carmen, en nog andere melodieën die tot het algemeen menselijk erfgoed behoorden

Het orkest van het mannenkamp in Auschwitz speelde elke zondag van 1942 tot 1944, en net zo het orkest in Natzweiler-Struthof. Hetzelfde geldt voor het orkest van het vrouwenkamp in Birkenau. Al naargelang de weersomstandigheden vonden de concerten plaats voor of in de Sauna.

\section{Spelen voor de private ontspanning van SS'ers}

In talrijke getuigenissen wordt er melding van gemaakt dat muziek een belangrijke rol speelde in de ontspanning van de SSers en dat sommigen er een bijzondere voorkeur voor hadden. Rottenführer Pery Broad, die in Auschwitz instond voor het selectieproces bij de gaskamers, was zelf een virtuoze accordeonist en bezocht geregeld het Block van het orkest. De orkesten en diverse ensembles stonden voor privégebruik permanent ter beschikking van de SS'ers; op elk moment konden die privégebrik pernanden die eisen dat een musicus voor hen speelde. Nog in Birkenau kwamen dr. Josef Mengele en kampcommandant Kramer na een selectie geregeld luisteren naar het orkest
van het vrouwenkamp. het vrouwenkamp.

Dat beulen ter ontspanning luisterden naar jazz, in de nazi-ideologie het perfecte voorbeeld van Entartete Musik, was een grote paradox van het muziekleven in de kampen. Eind 1941 verhardden de naziautoriteiten de strafmaatregelen tegen de jeugdgroepen (Swing-Jugend) die jazz speelden en beluisterden, vaak als uiting van protest tegen de macht. Behalve een strenge tuchtiging riskeerde de overtreder twee tot drie jaar opsluiting of zelfs deportatie naar een concentratiekamp, en ook inbeslagneming van zijn bezittingen. Dat in Auschwitz, Buchenwald, Mauthausen en Theresienstadt jazzformaties bestonden - telkens ontstan met de min of meer en Theïlesin of meer officiële goedkeuring van de SS en de plaatselijke kampadministratie - is veelbetekenend voor de achteruitgang van het principe van raszuiverheid, in naam waarvan die autoriteiten geacht werden te handelen. De jazzgroep in Auschwitz lijkt uitsluitend voor SS-orgieën te hebben bestaan. In Buchenwald werd de bigband Rythmus zonder goedkeuring opgericht in de zomer van 1943, een periode waarin de SS het beheer van het kampleven had overgelaten aan vertegenwoordigers van de gevangenen. Het repertoire bestond uit composities van Duke Ellington, Cole Porter, Glenn Miller, W. C. Handy, Irving Berlin, Louis Armstrong, Artie Shaw en Fats Waller. Toen de SS het bestaan van Rythmus vernam, gaven ze toestemming om te concerteren voor andere gevangenen en ze lieten de bigband herhaaldelijk opdraven in andere kamen. Mauthausen had eveneens een klein jazzensemble, ook weer opgericht zonder pen. Monder goedkeuring, dat vanaf de zoner van 1944 voor de gevangenen speelde. Toen de SS daarvan hoorde, eisten ze dat de groep feestjes in het lokale bordeel kwam opvrolijken. De groep verkoos zichzelf op te heffen, liever dan gevolg te geven aan dat bevel.

\section{Spelen tijdens officiële plechtigheden}

De orkesten speelden ook tijdens officiële plechtigheden als de verjaardag van de Führer, inspecties of bezoek van SS-gezagsdragers. Bepaalde kampbevelhebbers die trots waren op hun orkest aarzelden niet om ermee te pronken tijdens bezoeken aan andere kampen. Szymon Laks vermeldt dat hij in allerijl een loflied moest componeren voor de verjardag van Lagerführer en Sturmbannführer Schwarzhuber in poneren voor de verjaardag van Lagerfuhrer en Sturmbannfuhrer Schwarzhuber in Auschwitz, waar Heinrich Himmler ooit werd onthaald op het trompetgeschal uit
Aida. In 1941 in Dachau gebeurde dat met een polka. 


\section{De realiteit van het kampleven verdoezelen}

De orkesten en muziek in het algemeen werden ook gebruikt om de realiteit van de concentratiekampen te verdoezelen voor externe waarnemers. Met die propaganda werd getracht zand in de ogen te strooien van de internationale opinie en de mensen die in de buurt van de kampen woonden. Zo werd het orkest van het Esterwegen-kamp - waar de pacifist, naziopposant en Nobelprijswinnaar (in 1936) voor de vrede Carl von Ossietzky (1889-1938) werd geïnterneerd-ingeschakeld voor voor devedeCar een bezoek van het internationale Rode Kruis. Het getto van Theresienstadt werd opgericht voor propagandadoeleinden om te laten zien hoezer nai-Duitsland zich wel om het lot van de Joden bekommerde; in juli 1944 werd het eveneens bezocht door het internationale Rode Kruis.

\section{Het selectieproces in de vernietigingscentra begeleiden}

Als gevolg van tegenstrijdige getuigenissen is deze functie controversieel. Het selectieproces hield in dat de SS'ers bij elk nieuw transport beslisten welke gedeporteerden ze onmiddellijk naar de gaskamer stuurden en welke ze zouden sparen om a werkkrachten in te zetten. In hetbijzonder wat Birkenua werkig getuigen dat er bij deze macabere taak een orkest aanwezig was, terwijl anderen he in het vrouwenorkest, vert

De Duitsers gebruikten het orkest ook om de gedeporteerde Joden te misleiden. Zo konden die zich voorstellen dat ze naar Auschwitz waren gebracht om te werken en dat het er nog niet zo kwaad kon zijn als er een orkest speelde.

Erika Rothschild, die naar Birkenau werd gedeporteerd, doet een vergelijkbaar verhaal:

Wie in Birkenau aankwam, werd uit de beestenwagens gehaald en in rijen opgesteld [...] onder begeleiding van het orkest; het bestond uit de beste musici onder de gevangenen. Al naargelang de plek waar de transporten vandaan kwamen, vertolkten ze Poolse,

Tsjechische of Hongaarse volksmuziek. Het orkest speelde, de SS'ers deelden klappen uit en je had geen tijd om na te denken... Sommigen werden het kamp in geduwd, anderen richting verbrandingsovens.

Louis Bannet en Shmuel Gogol, respectievelijk trompettist en harmonicaspeler in het mannenorkest, halen gelijksoortige scènes aan.

Szymon Laks daarentegen ontkent elke betrokkenheid van het orkest dat hij dirigeerde bij het selectieproces:

Wat Birkenau betreft, moet ik dat onvoorwaardelijk ontkennen. Het orkest nam niet deel aan dergelijke vertoningen. Ik pleit niet het orkest vrij, maar de Duitsers, want die houden te veel van muziek om haar voor zo'n prozaïsche doeleinden te gebruiken. Het kwam natuurlijk wel eens voor dat we op ons podium speelden terwijl aan de andere kant van de prikkeldraadversperring rijen veroordeelden richting gaskamers gingen, maar dat was louter toeval.

Ook Anita Lasker-Wallfisch en de Française Fania Fénelon, allebei lid van het vrouwenorkest, spreken een dergelijke medewerking tegen.

Het antwoord op die tegenstrijdigheden vinden we waarschijnlijk in het relaas van Helena Dunicz-Niwinska, die nog vertelt:

Tijdens de zondagse concerten speelden we buiten, tussen de barakken. We vertolkten ouvertures, marsen, aria's uit opera's en operettes. De mensen die uit de wagons kwamen, hoorden natuurlijk onze muziek voor ze geselecteerd en naar de verbrandingsovens gebracht werden. En wij zagen hen, we wisten wel degelijk wat daar gebeurde.

Het Block van het orkest bevond zich vlak bij het platform en hoogstwaarschijnijk konden de gedeporteerden het orkest horen spelen tijdens de zondagse openluchtconcerten, die plaatsvonden ongeacht of er nu transporten aankwamen of niet Tegenwordig zijn de historici van mening dat, behoudens uitzondering of niet. Tenwer selectieproces noch het vermoorden van gevangenen met muziek gepaard ging. Maar de musici waren zich er wel van bewust dat ze werden gehoord, en die herinnering had een intense psychologische impact voor de overlevenden. Tijdens de laatste dagen van Bergen-Belsen werden de gevangenen trouwens verplicht om meer dan 2000 lijken naar massagraven te dragen terwijl twee (elkaar aflossende) zigeunerorkesten dansmuziek speelden.

\section{KAMPORKESTEN: PERCEPTIE}

\section{De orkesten in de ogen van de gevangenen..}

In die context, tussen officiële taken en ontspanning voor de gedetineerden, hadden de musici een ambivalent statuut: als lid van orkesten onder SS-bevel waren ze doorgaans onderworpen aan een lichter arbeidsregime, waardoor ze konden repeteren en ook relatief beschermd waren tegen de pesterijen en mishandelingen van hun bewakers. In het algemeen hadden ze betere levensomstandigheden dan de andere gevangenen, werkten ze in een verwarmde omgeving en kregen ze in verhouding meer voedsel. In vergelijking met de overvloedig aanwezige arbeidskrachten, die tot de dood werden uitgebuit voor de Duitse oorlogsindustrie, werden goede musici in de kampen beschermd omdat ze met zo weinig waren. Daarom waren ze

De meeste vrouwen waren gemeen tegen ons, want we waren bevoorrecht. Niet vanwege het voedsel, maar omdat we een eigen barak hadden die verwarmd was met 
een kachel. We hadden goede kleren, terwijl de andere vrouwen's winters blootsvoets gingen. Wij konden elke dag een douche nemen.

Inlijving in een kamporkest betekende hoe dan ook dat je een grotere kans op overleven had, zoals Anita Lasker-Wallfisch getuigt in haar boek De celliste van Auschwitz. Helena Dunicz-Niwinska geeft aan:

De gevangenen reageerden heel divers. Sommigen waren blij dat ze via de muziek de harde kamprealiteit van elke dag konden vergeten. Anderen waren geschokt door het feit dat wij muziek speelden terwijl de vlammen uit de schoorstenen van de verbrandingsovens sloegen. Daar konden ze niet bij. Ook wij musici gingen heel verschillend om met die ervaring. Sommigen waren er kapot van dat ze in dergelijke omstandigheden moesten concerteren,

De meningen verschillen over hoe muziek het moreel van de gevangenen in de kampen beïnvloedde. Voor sommigen was het een manier om te ontspannen en de verschrikkelijke levensomstandigheden te vergeten. Voor anderen was ze van weinig of geen nut. In Kapelmeester van Auschwitz de in 1948 verschenen memoires over zijn gevangenschap gat Szymon Laks heftig in tegen het 'seïdealiseerde'beeld van muziek in de kampen:

Los van wat ik zelf heb gezien en gehoord, deed ik overal ter wereld navraag bij vrienden en kennissen die opgesloten zaten in verschillende concentratiekampen. Zij zijn bijna allen van mening dat in de kampen alleen alledaagse liedjes werden gespeeld, van lokale inslag of simpelweg volkse deuntjes, en die hadden weinig te maken met wat voor geesteskracht dan ook. [...] Het is niet leuk om legenden te ontkrachten. Maar het is nog minder leuk om te lezen dat muziek 'uitgerekend in de context van de concentratiekampen' een medicijn was voor de zieke ziel van gevangenen. Want dat is niet correct! [...] In werkelijkheid kwam de ware aard van gevangenen op een paar uitzonderingen na ringen

De intrinsieke kwalteit van de muziek die in dekampen wedgespeld beijkt Laks hier weliswaar als professioneel musicus.

\section{... en in de ogen van de beulen}

We geven opnieuw het woord aan Helena Dunicz-Niwinska:

De Duitsers wilden dat we op zondag speelden. Maar het is niet zo dat we alleen voor hen speelden. Het waren 'zondagsconcerten' voor de gevangenen, maar de Duitsers kwamen ook luisteren. Ook de SS'ers uit het kantoor van de bevelhebber woonden onze repetities bij, niet volledig, maar voor korte tijd. Bijvoorbeeld de bevelhebber van het vrouwenkamp, Hössler en Maria Mandl. [...] Zelfs dokter Mengele bezocht ons Block. In de zomer vonden de zondagse concerten plaats op het kruispunt in het vrouwenkamp of tussen de Blocks van het ziekenhuis. In de winter speelden we in een ziekenhuisblok. Alma Rosé stelde alles in het werk om een zo hoog mogelijk niveau te halen. Ze deed heel hard haar best. We waren ons ervan bewust dat we de Duitsers hielpen, en niet alleen bij het marcheren van de arbeidsploegen. Gedurende de periode dat Alma Rosé het orkest leidde, was het niveau zo hoog dat de Duitsers simpelweg blij waren dat ze in het vrouw dat niet. Ze waren er trots op, ze schepten erover op. Ze pronkten met ons bij externen die de werking van het kamp kwamen controleren.

De orkesten die voor de SS'ers concerteerden en hun zo gedurende een paar uur het gevoel gaven dat ze een 'normaal' leven leidden, werkten ongewild mee aan de oorlogsinspanning van de nazi's. De orkesten werden trouwens vaak gebruikt in een machtsspel tussen de kampcommandanten; die vergeleken onderling de kwaliteit van hun orkesten en organiseerden er concerten mee in naburige kampen.

\section{OVER HET CORRECTE GEBRUIK VAN DE MUZIEK}

UIT DE CONCENTRATIEKAMPEN

In het voorjaar van 2009 werkte het Ensemble Voix Etouffées voor het eerst in zijn prille bestaan samen met het museum Auschwitz-Birkenau, in het raam van het Europese programma 'Europa voor de burger'. De formatie werd opgericht door ondergetekende, die vanaf nu de eerste persoon zal gebruiken en de lezer meteen om verschoning vraagt voor deze inbreuk op de academische traditie. Sinds zijn oprichting in 2003 richt het ensemble zich op componisten die het slachtoffer waren van het nazisme, verenigd onder het label Entartete Musik, de soortnaam die de nazi's hun hadden gegeven. Het was onvermijdelijk dat we ons ooit zouden gaan bezighouden met muziek uit de concentratiekampen zelf Op een mooie deg in april 2009 bevonden we ons dus in Auschwitz en speelden daar werken op de plek war 2009 bevond de componisten ervan zozeer hadden geleden. Het concert kon om praktische en ethische redenen niet in het kamp zelf plaatsvinden en daarom had de publicrelationsafdeling van het museum als locatie de muziekschool van Oświęcim gekozen. In het raam van een vormingsprogramma over de Holocaust had het ook een samenkomst belegd tussen onze groep en leraren uit de regio Klein-Polen.

Ondertussen traden we zo al zesmaal op, waarbij we steeds meer konden rekenen op de medewerking van de leerlingen van de muziekschool (meer bepaald het koor) en hun leraren, en ook van een groep studenten van de ENSAAMA (Ecole nationale supérieure des arts appliqués et des métiers d’art) uit Parijs. Op het programma van die bestendige Frans-Poolse uitwisseling stonden onder meer volgende werken: de kinderopera Brundibar Van Hans Krás (1899-1944), die in Theresient tussen kinder 1942 en 1944 meer dan vijttig keer werdopgevordvoor de conponist en de zanger- 
die een tijdje dirigent was van het mannenorkest in Auschwitz I; en liederen van Ilse Weber (geboren 1902 - vermoord in Auschwitz in oktober 1944), met nieuwe arrangementen voor het schoolkoor. Onze allereerste samenwerking was in tweevoudig opzicht een revelatie: niet alleen vanwege de plek en de geest die er hing, maar ook vanwege de bijdrage die we met onze muziek konden leveren aan het doorgeven van de geschiedenis over de Holocaust.

Sindsdien ontwikkelde het Forum Voix Etouffées een intense pedagogische activiteit in samenwerking met herdenkingsplekken betreffende de deportatie, ctreffende de deportatie bijvoorbeeld het museum in Struthof, het Camp des Milles-museum, het Cerci (Centre d'étude et de recherche sur les camps d'internement du Loiret), het Mémorial de l'Alsace-Moselle in Schirmeck en de Gedenkstätte Langenstein-Zwieberge in Sachsen-Anhalt. In bepaalde gevallen konden we rekenen op directe getuigen als Eva Hermannová, die zong in het Brundibár-koor in Theresienstadt. Andere workshops verliepen in samenwerking met internationale organisaties als de Raad van Europa, bijvoorbeeld in Frankrijk en Bulgarije; in dat laatste land werden leraren opgeleid om de deportatie en de Holocaust via muziek te bespreken. Recent hebben we een samenwerking opgestart met verschillende regionale afdelingen van het Canopé-netwerk van het Franse ministerie van Onderwijs, waardoor we heel wat instellingen van hetalgemenonderwijs kondenberiken. insterichemen bij ons aan bod, want we zijn actiefbinnen een netwe dit een vijtienta en in een historisch en politiek perspectiefgeplaatst. Om via muziek de deportatie in het algemeen en de Holocaust in het bijzonder te herdenken is het Ensemble Voix Etouffées trouwens geregeld te gast bij de Europese Commissie in Brussel en in Europese landen als Litouwen, Macedonië, Bulgarije, Oostenrijk en Duitsland. Maar na verloop van tijd en ondanks de grote verdiensten riep die militante activiteit ook heel wat vragen op, ja zelfs contradicties van deontologische, wetenschappelijke, politieke en muzikale aard. Daardoor zijn we noodgedwongen gaan nadenken over wat je de 'goede praktijk' van de gedachtenis zou kunnen noemen, en ook wat Georges Bensoussan het 'correcte sebruik' darvan noemt.

Het is niet zonder risico om voor het publiek werken te vertolken die werden gecomponeerd tijdens opsluiting in naziconcentratiekampen en zelfs werden uitgevoerd door de orkesten die het onderwerp van dit artikel uitmaken. Omdat in een dergelijk project uiteenlopende disciplines meespelen - behalve muziek gaat het om geschiedenis, germanistiek, filosofie, politieke wetenschappen en andere - en omdat in elk daarvan de waarheid in details schuilt, moet je deze onderwerpen met omzichtigheid, kennis van zaken en zin voor nuance behandelen. De 'kampmuziek' die tijdens de concerten vaak wordt behandeld - een voorwendsel om zowel werken te programmeren van Olivier Messiaen (een krijgsgevangene beschermd door het Verdrag van Genève) als van Ullmann (vermoord in Auschwitz vanwege zijn Joodse afkomst) - is als concept niet alleen duister, mar je kunt het zelfs bijna negatioafkom - is als concept niet all werkelijkheden die helemaal niets met elkaar te maken hebben op een hoop gegooid.
In juridisch opzicht is oorlog immers geen misdaad tegen de mensheid, terwijl volkerenmoor dat wel is. Ik weet wel dat de meeste van dergelijke projecten veeleer het resultaat zijn van onwetendheid dan van intellectuele oneerlijkheid, maar dat mag geen excuus zijn. Door dit soort historische benaderingwordteen 'Holocaustbusiness' in stand sehouden warran de motieven, die stelnstanctis geuter mededogen en compassie, pedagog op louter mogisch ondoeltreffend zijn en deontologisch hoogst aanchtbaar.

Ook problematisch is de volgende contradictie: het concept 'concentratiekampmuziek' slaat in werkelijkheid meer op sociologie dan op kunst meer op een geheel van culturele praktijken dan een op een creatief corpus in de traditionele zin

van het woord. Van het minieme aantal composities waarvan het muzikale belang de ontstaansgeschiedenis overstijgt, behoren de bewaard gebleven werken tot het 'normale' muzikale repertoire, niet om at ze direct verwijzen nar de concentra'no tiekampen en histieke waarde. Brundibár bijvoorbeeld wordt tegenwoordig in de muziek voor de jeugd met recht en reden naar waarde geschat (en werd trouwens niet gecomponeerd in Theresienstadt, maar in Praag in 1938). Het is een uitstekend instrument om de Holocaust aan te kaarten, omdat het een hoogstaand werk is dat je als zodanig kunt appreciëren, maar dat tegelijkertijd verwijst naar de gebeurtenissen in Theresienstadt.

Het muziekleven in de nazikampen is maar één domein van het Europese cultuurleven dat door het Hitlerregime enorme schade opliep. Sinds een twintigtal jaar worden inspanningen ondernomen om te doen herleven wat zo kapot is gegaan - een moeilijke opgave in een wereld waarin de herinnering vaak een leeg motto blijkt te zijn Om recht te doen an dit vergeten repertoire is het belangiijk alleen meesterwerken tebrengerwerken te brengen andere aanpak risker we niemand een dienst als we middelmatige werken brengen met het excuus dat de componist het slachtoffer werd van de nazi's.

Muzikale sensibiliteit moet in dit verband gepaard gaan met een grote wetenschappelijke en historische veeleisendheid. Zo kunnen we helpen om een 'positieve' en constructieve gedachtenis op te bouwen van het door het nazisme veroorzaakte onheil. 